\title{
Contamination content introduced with rain water to the rivers after they have been cleaned in separators of petroleum compounds
}

\author{
Dawid Łapiński ${ }^{1 *}$, Józefa Wiater $^{1}$ \\ ${ }^{1}$ Department of technology in engineering and environmental protection, Faculty of Civil and \\ Environmental Engineering, Bialystok University of Technology, Wiejska 45A, Poland
}

\begin{abstract}
The article presents the results of rainwater quality studies. The rainwater flowing from the surface of urbanized areas of the city of Białystok discharged into the river after they have been cleansed with separators petroleum compounds. Also discussed are issues related to with rain water and the problem to need develop them. Contaminated flushes from sealed surfaces such as street squares, sidewalks, parking lots, etc., during periods of rain or thawing, pose a serious threat to the natural environment. The work presents analyzes of such pollutants as general slurry, heavy metals, chlorides, $\mathrm{BOD}_{5}, \mathrm{COD}$, etc., which once penetrate rainwater into Biała River. Five measurement and control points located in a typical urban drainage basin were selected for the study. The tests were taken in the spring of 2017 in two measuring series. The first series was taken during the long-term precipitation, while the second was after the almost one-month rain-free period, at the time of the first precipitation.
\end{abstract}

Keywords: Rain water; Precipitation; heavy metals; separators; White River.

\section{ISSUES RAINWATER}

The development of civilization and the increase of the urban areas has forced the need for rainwater runoff from the surface. The priority is to collect them as quickly as possible from squares, streets, sidewalks and roofs, and next drain to the rain drain or landwater receiver[1,20]. Contaminated flushes from sealed surfaces such as street squares, sidewalks, parking lots, etc., during periods of rain or thawing, pose a serious threat to the natural environment $[2,13]$. In urban areas, it is a disorder of the hydrological cycle resulting from the growth surface of the impermeable and significant reduction in retention capacity and infiltration of rainwater. Watercourses in urbanized catchments, especially in big cities, become the main receivers of sewage and highly contaminated surface runoff, which causes their chemical and hygiene-sanitary conditions to deteriorate[11]. The search for a rational way of treating rainwater is one of the most urgent challenges in water management.

\footnotetext{
Corresponding author:d.lapinski@pb.edu.pl
} 
Rainwater is already contaminated during rainfall as a result of contact with contaminated atmospheric air. Raindrops capture in atmosphere contained it inter alia, volatile dust, $\mathrm{SO}_{2}, \mathrm{NO}_{2}, \mathrm{CO}_{2}$, fumes and chemicals from industrial areas[8]. The next stage of further pollution of the precipitation is surface runoff. The pollutants washed from the catchment area such as streets, squares, roofs, parks and pavements include sand, gravel, dust, rubbish, salt from the prevention of black ice, tire abrasion products, leaves and other parts of plants, fuel spills, etc. [15,16].The content of impurities, both organic and nonorganic, in rain waters is very diverse. The amount and type of pollutants entering rainwater depends mainly on the type of catchment and the way it is managed, as well as the time between successive rainfalls[20]. On the composition of the water is mainly influenced: type of surface of streets, squares and sidewalks, density of road network and traffic intensity, organization and method of street cleaning, method of anti-glaze control, participation of green areas in the city, intensity and duration of rain, as well as many other factors $[3,4]$. include:

The main pollutants and their describing parameters occurring in rainwater can

- heavy metals (zinc, chromium, cadmium, lead, nickel, copper)

- $\quad$ aromatic hydrocarbons (benzo [a] pyrene, pyrene, naphthalene)

- total suspension, BOD, COD, nitrogen, phosphorus, anions, cations, conductivity, $\mathrm{pH}$

The content of pollutants changes during rainfall, in general their concentration is the highest in the initial stage of rainfall, because the first runoff washes off the terrain surfaces[2]. This is especially important after long periods without precipitation. This phenomenon is caused by the pollution not only from the surface, but also from impurities deposited in the dewatering devices[3,18]. One of the main sources of rainwater and snowmelt pollution is motorization. Runoffs from roads are loaded with significant concentrations of general suspended solids, COD, ether extract, petroleum substances and heavy metals. Heavy metals are found in rainwater in the form of dissolved salts, ions or insoluble compounds[1,18]. Higher metal concentrations are usually observed in runoff from industrial areas, rather than from residential areas.

Looking at literature, both Polish and foreign, related to the problem of rainwater, one can come across various definitions and formulations of rainwater or rainwater. In the Polish legal system, the terms "rainwater" and "meltwater" are not clearly defined[1,3,7,11]. However, in various legal acts, the definition of rainfall sewage and meltwater sewage appears. Pursuant to the Environmental Protection Law Act of 27 April 2001 , by means of sewage is meant, among other things, rainwater or snowmelt, entered into open or closed sewage systems, originating from contaminated surfaces with permanent surface, in particular from cities, ports, airports, industrial, commercial, service and storage areas, transport bases, roads and parking lots[22]. This definition was repeated in the Act of 18 July 2001 on Water Law. The same entry is also made in the Act of June 7, 2001 on collective water supply and collective sewage disposal[23]. The basic legal acts talking about the possibilities of development and quality standards for rainwater are the aforementioned Water Law from July 18, 2001. with d. and Regulation of the Minister of the Environment on July 24, 2006 on the conditions to be met when introducing sewage into waters or into the ground, and on particularly harmful substances. This regulation defines only the values of suspension and hydrocarbons in rainwater discharged to the receiver and states that they should not contain contaminants in the amount of $100 \mathrm{mg} \cdot \mathrm{dm}$ ${ }^{-3}$ total suspension and $15 \mathrm{mg} \cdot \mathrm{dm}^{-3}$ petroleum substances[24]. However, other dangerous substances are omitted, such as heavy metals, which due to their bioaccumulation potential may have a negative impact on the environment, in particular on rainwater receivers.

Rainwater from urbanized areas can be drained in a conventional way by collective 
sewage systems or, alternatively, managed at the place of their creation. The main method of pre-treating rainwater, before they are discharged to the water receiver, are devices based on physical methods mainly using sedimentation and filtration processes[11]. The most important parameter allowing to determine the negative impact of rainwater on the water receiver is the in which the accumulation of most pollutants takes place. Even up to $90 \%$ of the total suspension is a mineral slurry in the form of sand, gravel and soil particles, which absorbs other impurities on its porous surface. Strict relations were found between the amount of suspension and the chemical and biochemical oxygen demand as well as the concentration of heavy metals[5,6]. The most commonly used devices for preclining rain watercourses include various types of separators, settling tanks, absorbent wells, sediment ponds, soil filters, etc.[7].

\section{Subject and methodology of research}

Within the framework as part of the research carried out at the Department of Technology in Engineering and Environmental Protection, an analysis of the composition of rainwater pollutants from a selected catchment in the agglomeration of the city of Białystok was carried out. A catchment located in the south-eastern part of the city, characterized by diversified buildings (high- and medium-sized housing estates, lowdetached, single-family neighborhoods, service and recreation areas) and the presence of the main communication glazing was selected for the research. Five measurement and control points have been selected as shown in the figure below.

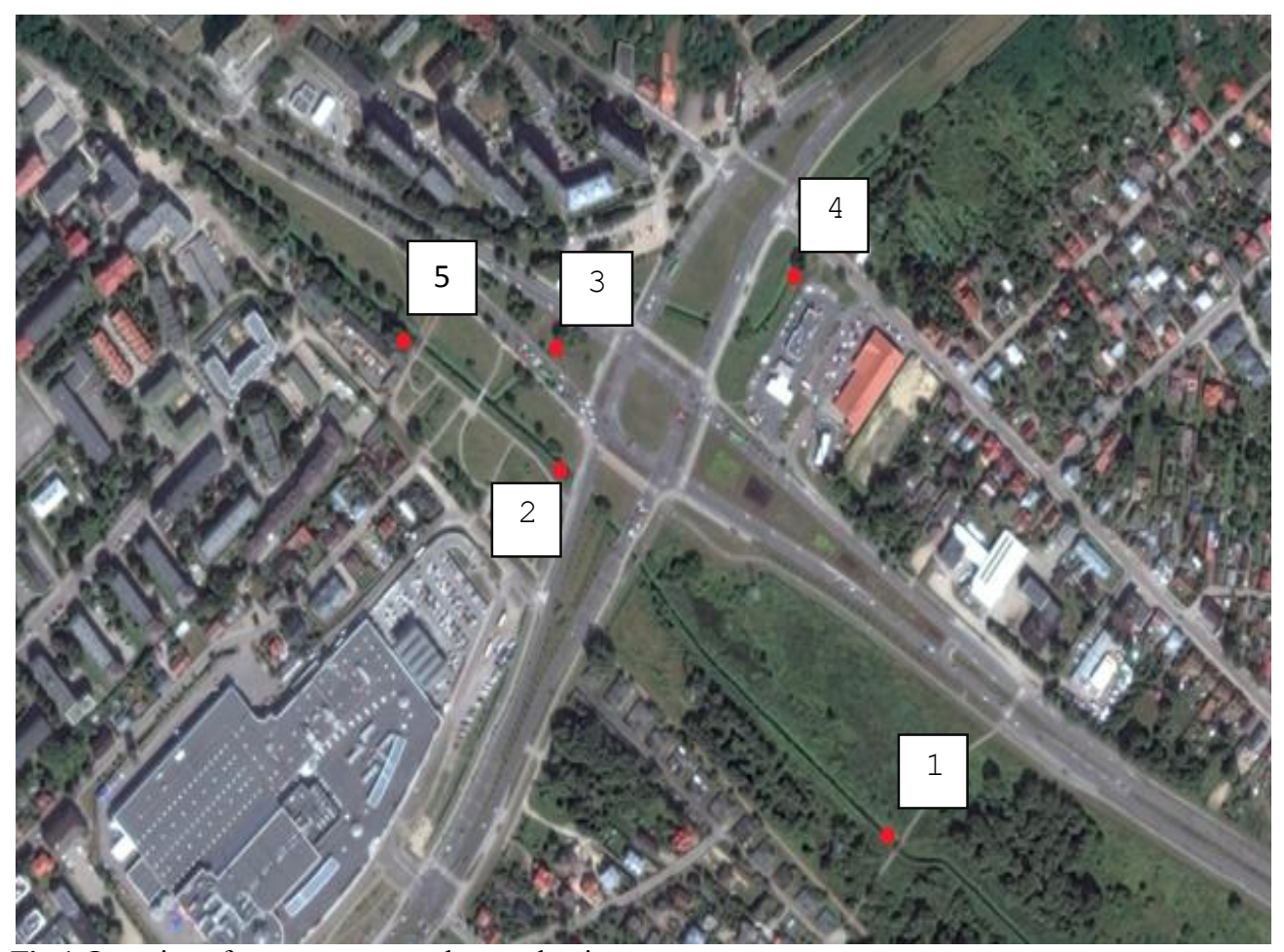

Fig 1. Location of measurement and control points.

Research samples were effluents from the separators of petroleum compounds located in the city of Białystok as well as water taken from the Biała River. The Biała River is a 
fourth-order river, a left tributary of Supraśl. It takes its origin not far from the Protasy village and its length is $32.7 \mathrm{~km}$. Constant tributaries of Biała are: the foot from the Upper Dojlid, Dolistówka and Bażantarka. The river is strongly regulated, some of its sections are rectilinear with technically formed banks and outlets of storm water drainage[9].

Samples were taken in April and May 2017. It was the period of spring rainfall characterized by various types of intensity and their occurrence time. It was important to take samples in the first 20 minutes of atmospheric precipitation because, according to literature data, the highest concentration of contaminants rinsed off the land surface occurs $[17,19,20]$.Samples for testing were taken in the coastal zone, at the outlet of separators (example drawing 2) and from the water depth of the river. The collected samples without fixation were immediately transported to the laboratory in order to determine the selected indicators. In the water collected, the following were determined: total suspension by the weigh methodt, $\mathrm{BOD}_{5}$ determined by respiromotor method using the OXI TOP kit, COD by the dichromate method using a HACH LANGE DR / 5000 spectrophotometer, anions and cations using a Thermo Scientific ICS 5000+ ionograph, heavy metals by the ASA method on atomic absorption spectrometer with Thermo Scientific iCE3400 electrothermal atomization and $\mathrm{pH}$ and conductivity by potentiometric method. Determinations were made according to current regulations or on the basis of the commonly used and recommended by the scientific literature analytical methodologies.

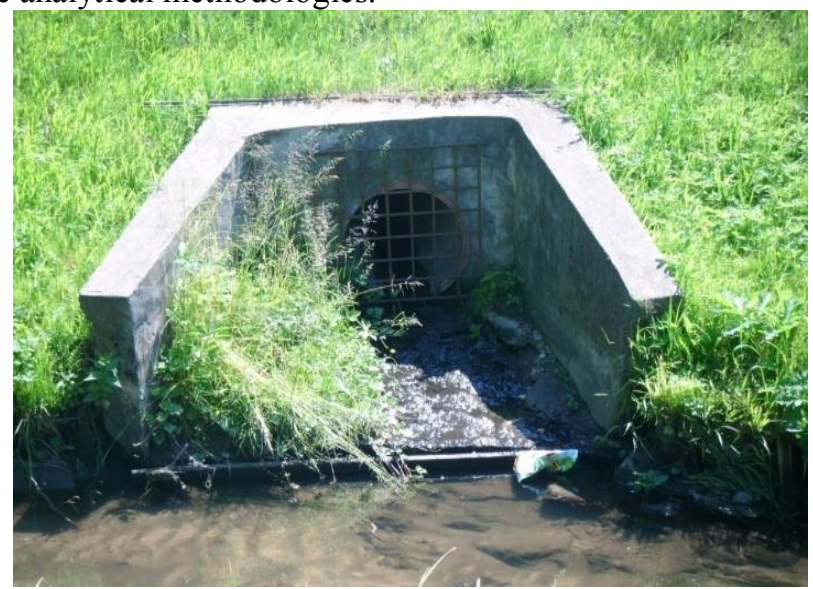

Fig 2. Measurement and control point no. 3, Outlet from petroleum separator.

\section{Research results}

Tables 1,2,3,4,5 and 6 show the results of the water samples tested. Results are the arithmetic mean of the three repetitions. The conducted research showed a very varied content of individual parameters and confirmed the information on high variability of the pollutant indicators in the case of rainwater studied in the literature[2,10,12,18]. Measurement points 1 and 5 were water taken from the Biała River before supplying rainwater from separators and supplying rainwater. The points 2,3,4 were sewage from the outlet selected for the analysis of separators. 
Table 1. Basic physicochemical parameters of tested. First series of research.

\begin{tabular}{|c|c|c|c|c|c|c|}
\hline Parameter & Unit & 1 & 2 & 3 & 4 & 5 \\
\hline $\mathrm{pH}$ & - & 8,14 & 8,23 & 8,11 & 8,09 & 8,12 \\
\hline $\mathrm{O}_{2}$ & $\mathrm{mg} / \mathrm{l}$ & 10,06 & 9,25 & 8,35 & 9,25 & 10,11 \\
\hline Temperature & ${ }^{\circ} \mathrm{C}$ & 17,70 & 17,30 & 17,90 & 17,60 & 17,00 \\
\hline Conductivity & $\mu \mathrm{S} / \mathrm{cm}$ & 517,00 & 987,00 & 1208,00 & 1031,00 & 618,00 \\
\hline \multirow{2}{*}{ Turbidity } & $\mathrm{mg} / 1$ & 26,00 & 20,00 & 13,50 & 7,20 & 21,00 \\
\cline { 2 - 7 } & $\mathrm{FAU}$ & 73,00 & 19,00 & 28,00 & 22,00 & 62,00 \\
\cline { 2 - 7 } & $\mathrm{NTU}$ & 10,50 & 7,65 & 11,50 & 9,19 & 6,51 \\
\hline Color & $\mathrm{mg} \mathrm{Pt} / 1$ & 64,00 & 57,67 & 24,00 & 22,83 & 56,00 \\
\hline Basicity Zm & $\mathrm{mval} / \mathrm{dm}^{3}$ & 4,00 & 5,50 & 5,60 & 3,60 & 4,40 \\
\hline Overall acidity & $\mathrm{mval} / \mathrm{dm}^{3}$ & 2,20 & 2,60 & 3,30 & 1,76 & 2,86 \\
\hline Hardness & $\mathrm{mval} / \mathrm{dm}^{3}$ & 5,00 & 6,48 & 6,84 & 4,40 & 5,44 \\
\hline Total suspension & $\mathrm{mg} / 1$ & 163,00 & 115,00 & 87,00 & 72,00 & 120,00 \\
\hline BOD 5 & $\mathrm{mg} / 1$ & 4,00 & 5,00 & 2,00 & 0,00 & 1,00 \\
\hline COD & $\mathrm{mg} / 1$ & 53,50 & 55,50 & 44,00 & 28,00 & 47,00 \\
\hline
\end{tabular}

Table 2. Basic physicochemical parameters of tested. Second series of research.

\begin{tabular}{|c|c|c|c|c|c|c|}
\hline Parameter & Unit & 1 & 2 & 3 & 4 & 5 \\
\hline $\mathrm{pH}$ & - & 8,03 & 7,38 & 7,72 & 7,68 & 7,88 \\
\hline $\mathrm{O}_{2}$ & $\mathrm{mg} / \mathrm{l}$ & 8,56 & 8,17 & 8,13 & 8,06 & 7,92 \\
\hline Temperature & ${ }^{\circ} \mathrm{C}$ & 20,30 & 20,90 & 20,80 & 20,50 & 20,70 \\
\hline Conductivity & $\mu \mathrm{S} / \mathrm{cm}$ & 434,00 & 527,00 & 1127,00 & 674,00 & 617,00 \\
\hline \multirow{3}{*}{ Turbidity } & $\mathrm{mg} / \mathrm{l}$ & 20,40 & 398,90 & 214,30 & 220,10 & 56,40 \\
\cline { 2 - 7 } & $\mathrm{FAU}$ & 34,60 & 526,00 & 254,00 & 253,00 & 75,00 \\
\cline { 2 - 7 } & $\mathrm{NTU}$ & 25,40 & 357,00 & 162,00 & 159,00 & 51,10 \\
\hline Color & $\mathrm{mg} \mathrm{Pt} / 1$ & 55,00 & 330,00 & 216,00 & 190,00 & 105,00 \\
\hline Basicity Zm & $\mathrm{mval} / \mathrm{dm}^{3}$ & 3,40 & 2,80 & 4,50 & 2,60 & 3,50 \\
\hline Overall acidity & $\mathrm{mval} / \mathrm{dm}^{3}$ & 1,32 & 2,64 & 1,76 & 1,54 & 1,48 \\
\hline Hardness & $\mathrm{mval} / \mathrm{dm}^{3}$ & 4,60 & 7,80 & 8,12 & 4,00 & 5,28 \\
\hline Total suspension & $\mathrm{mg} / 1$ & 349,00 & 640,00 & 324,00 & 321,00 & 182,00 \\
\hline BOD & $\mathrm{mg} / 1$ & 5,00 & 50,00 & 25,00 & 31,00 & 12,00 \\
\hline COD & $\mathrm{mg} / 1$ & 106,00 & 453,00 & 317,00 & 242,00 & 140,00 \\
\hline
\end{tabular}


Table 1 and 2 shows significant differences in the individual quality parameters of the waters tested. They result from the aforementioned fact that the first series was collected during the rain but during the few days of rain that washed away most of the contaminants in the previous days, while the second series was carried out after a long rainless period and during the sampling we managed to collect the so-called 'first' wave of "pollution carried along with precipitation.

The $\mathrm{pH}$ during the whole research period remained at a similar level and ranged from 7.38 to 8.23 . Similarly, the temperature of the tested water and wastewater from separators was constant in individual series. After the dry season there was a drop in dissolved oxygen at the control and control point 1 and 5 located on the river. Large differences were observed in the color and turbidity, especially for points 2.3 and 4 , ie at the outlet of separators. The values between the first and second measurement series differed by an order of magnitude. As an example, point no. 3 in which the color and turbidity value expressed in FAU has changed from about 20 to 200. Similarly as described in the literature, there was also observed a relationship between the increase in the amount of total suspension and the biological and chemical oxygen demand. For these parameters, there was also a change in the order of magnitude between the first and the second series of tests. Analyzing all the parameters presented in Table 1 and 2, a slight deterioration of water status in the Biała River was observed. However, the measurement and control points were located on a fairly short section of the examined river and to fully illustrate the impact of the urban agglomeration on its condition, it would be necessary to examine the water before and after Białystok. The content of dissolved cations and anions in water in both measurement series remained at a similar level. It can be concluded that the increase in the total suspension content does not affect dissolved cations and anions. Small changes can be observed only in the case of phosphates, nitrates and ammonium ions. This is probably due to the flushing of fertilizers from adjacent green areas and garden plots. Results of the studied anions and cations are presented in Table No. 3 and 4.

Table 3.Content of cations and anions in tested samples. First series of research.

\begin{tabular}{|c|c|c|c|c|c|c|}
\hline Parameter & Unit & 1 & 2 & 3 & 4 & 5 \\
\hline $\mathrm{F}^{-}$ & $\mathrm{mg} / 1$ & 0,13 & 0,10 & 0,11 & 0,12 & 0,13 \\
\hline $\mathrm{Cl}^{-}$ & $\mathrm{mg} / 1$ & 29,52 & 135,05 & 175,81 & 175,02 & 45,11 \\
\hline $\mathrm{Br}^{-}$ & $\mathrm{mg} / 1$ & 0,00 & 0,03 & 0,05 & 0,03 & 0,00 \\
\hline $\mathrm{NO}_{3}{ }^{-}$ & $\mathrm{mg} / 1$ & 3,31 & 7,92 & 23,22 & 29,04 & 9,13 \\
\hline $\mathrm{NO}_{2}^{-}$ & $\mathrm{mg} / 1$ & 0,03 & 0,06 & 0,41 & 0,13 & 0,13 \\
\hline $\mathrm{PO}_{4}{ }^{3-}$ & $\mathrm{mg} / 1$ & 0,01 & 0,02 & 1,93 & 1,91 & 0,07 \\
\hline $\mathrm{SO}_{4}{ }^{2-}$ & $\mathrm{mg} / 1$ & 30,38 & 50,60 & 47,78 & 51,11 & 38,43 \\
\hline $\mathrm{Na}^{+}$ & $\mathrm{mg} / 1$ & 29,70 & 118,20 & 176,40 & 204,60 & 69,90 \\
\hline $\mathrm{NH}_{4}^{+}$ & $\mathrm{mg} / 1$ & 0,40 & 1,20 & 3,20 & 2,10 & 1,30 \\
\hline $\mathrm{Mg}^{2+}$ & $\mathrm{mg} / 1$ & 22,40 & 35,40 & 29,60 & 23,60 & 24,90 \\
\hline $\mathrm{K}^{+}$ & $\mathrm{mg} / 1$ & 8,80 & 12,90 & 66,90 & 26,80 & 11,50 \\
\hline $\mathrm{Ca}^{2+}$ & $\mathrm{mg} / 1$ & 159,50 & 212,90 & 227,00 & 143,50 & 176,30 \\
\hline
\end{tabular}


Table 4. Content of cations and anions in tested samples. Second series of research.

\begin{tabular}{|c|c|c|c|c|c|c|}
\hline Parameter & Unit & 1 & 2 & 3 & 4 & 5 \\
\hline $\mathrm{F}^{-}$ & $\mathrm{mg} / 1$ & 0,13 & 0,12 & 0,10 & 0,07 & 0,10 \\
\hline $\mathrm{Cl}^{-}$ & $\mathrm{mg} / 1$ & 22,92 & 72,54 & 185,27 & 104,01 & 56,68 \\
\hline $\mathrm{Br}^{-}$ & $\mathrm{mg} / 1$ & 0,00 & 0,26 & 0,00 & 0,00 & 0,01 \\
\hline $\mathrm{NO}_{3}{ }^{-}$ & $\mathrm{mg} / 1$ & 2,06 & 11,65 & 20,33 & 13,91 & 11,71 \\
\hline $\mathrm{NO}_{2}{ }^{-}$ & $\mathrm{mg} / 1$ & 0,03 & 0,36 & 0,41 & 0,29 & 0,35 \\
\hline $\mathrm{PO}_{4}{ }^{3-}$ & $\mathrm{mg} / 1$ & 0,08 & 0,64 & 1,70 & 0,53 & 0,20 \\
\hline $\mathrm{SO}_{4}{ }^{2-}$ & $\mathrm{mg} / 1$ & 25,37 & 22,06 & 38,90 & 34,89 & 37,94 \\
\hline $\mathrm{Na}^{+}$ & $\mathrm{mg} / 1$ & 23,30 & 71,50 & 177,80 & 118,30 & 56,30 \\
\hline $\mathrm{NH}_{4}{ }^{+}$ & $\mathrm{mg} / 1$ & 0,40 & 5,80 & 1,80 & 3,80 & 1,40 \\
\hline $\mathrm{Mg}^{2+}$ & $\mathrm{mg} / 1$ & 19,30 & 12,00 & 25,10 & 14,50 & 22,90 \\
\hline $\mathrm{K}^{+}$ & $\mathrm{mg} / 1$ & 9,10 & 17,20 & 42,60 & 19,50 & 14,60 \\
\hline $\mathrm{Ca}^{2+}$ & $\mathrm{mg} / 1$ & 132,20 & 116,20 & 198,90 & 111,90 & 158,70 \\
\hline
\end{tabular}

Large differences were observed while the contents of individual elements and heavy metals. The results of tests on heavy metals and macronutrients are summarized in the Table No. 5 and 6.

Table 5. Content of macroelements and heavy metals in tested samples First series of research

\begin{tabular}{|c|c|c|c|c|c|c|}
\hline Parameter & Unit & 1 & 2 & 3 & 4 & 5 \\
\hline $\mathrm{Na}$ & $\mathrm{mg} / 1$ & 19,50 & 66,05 & 36,70 & 74,55 & 15,90 \\
\hline $\mathrm{Mg}$ & $\mathrm{mg} / 1$ & 6,55 & 13,05 & 6,68 & 7,73 & 6,60 \\
\hline $\mathrm{K}$ & $\mathrm{mg} / 1$ & 4,79 & 7,34 & 28,89 & 12,99 & 5,81 \\
\hline $\mathrm{Mn}$ & $\mu \mathrm{g} / 1$ & 59,50 & 127,50 & 430,50 & 64,00 & 67,50 \\
\hline $\mathrm{Fe}$ & $\mu \mathrm{g} / 1$ & 641,00 & 416,50 & 474,50 & 390,50 & 410,50 \\
\hline $\mathrm{Cr}$ & $\mu \mathrm{g} / 1$ & 0,00 & 5,00 & 0,00 & 0,00 & 5,00 \\
\hline $\mathrm{Ni}$ & $\mu \mathrm{g} / 1$ & 5,50 & 21,00 & 8,50 & 7,50 & 7,00 \\
\hline $\mathrm{Cu}$ & $\mu \mathrm{g} / 1$ & 5,50 & 26,50 & 20,50 & 12,00 & 10,00 \\
\hline $\mathrm{Zn}$ & $\mu \mathrm{g} / 1$ & 50,00 & 156,50 & 150,00 & 203,00 & 67,50 \\
\hline $\mathrm{Pb}$ & $\mu \mathrm{g} / 1$ & 0,00 & 5,50 & 2,00 & 0,00 & 1,26 \\
\hline $\mathrm{Cd}$ & $\mu \mathrm{g} / 1$ & 0,00 & 0,00 & 0,00 & 0,00 & 0,00 \\
\hline
\end{tabular}


Table 6. Content of macroelements and heavy metals in tested samples Second series of research

\begin{tabular}{|c|c|c|c|c|c|c|}
\hline Parameter & Unit & 1 & 2 & 3 & 4 & 5 \\
\hline $\mathrm{Na}$ & $\mathrm{mg} / 1$ & 35,43 & 295,90 & 243,10 & 250,80 & 85,90 \\
\hline $\mathrm{Mg}$ & $\mathrm{mg} / 1$ & 17,00 & 19,40 & 13,90 & 12,60 & 22,10 \\
\hline $\mathrm{K}$ & $\mathrm{mg} / 1$ & 14,35 & 49,47 & 33,02 & 26,99 & 20,51 \\
\hline $\mathrm{Mn}$ & $\mu \mathrm{g} / 1$ & 98,10 & 835,33 & 818,82 & 403,90 & 208,21 \\
\hline $\mathrm{Fe}$ & $\mu \mathrm{g} / 1$ & 1900,15 & 14693,68 & 7076,07 & 3348,35 & 2063,06 \\
\hline $\mathrm{Cr}$ & $\mu \mathrm{g} / 1$ & 3,00 & 29,53 & 19,02 & 8,51 & 6,01 \\
\hline $\mathrm{Ni}$ & $\mu \mathrm{g} / 1$ & 1,75 & 17,52 & 9,51 & 7,01 & 4,50 \\
\hline $\mathrm{Cu}$ & $\mu \mathrm{g} / 1$ & 8,01 & 105,11 & 98,60 & 54,05 & 17,52 \\
\hline $\mathrm{Zn}$ & $\mu \mathrm{g} / 1$ & 127,38 & 1158,16 & 660,66 & 500,00 & 223,22 \\
\hline $\mathrm{Pb}$ & $\mu \mathrm{g} / 1$ & 11,26 & 49,05 & 116,53 & 17,52 & 14,01 \\
\hline $\mathrm{Cd}$ & $\mu \mathrm{g} / 1$ & 65,07 & 349,00 & 718,72 & 254,25 & 190,19 \\
\hline
\end{tabular}

The content of heavy metals in the tested samples remained at level the microgram in liter and was similar to the values presented by other authors[14,18,19,20]. By using the previously quoted literature information, it can be concluded that most heavy metals are accumulated in the suspension, which explains the differences between their content in the first and second research series. This is most evident in the case of cadmium and lead which in the first series were practically absent or at the background level. The second research series confirms that rainwater discharged from squares and streets contains large amounts of heavy metals. When comparing heavy metal contents at 1 and 5 measurement and control points, small changes can be observed on the studied river section, despite their significant amounts supplied with rainwater, but it should be noted that according to other authors, heavy metals very quickly accumulate in sediments river[10,17,18].

\section{Conclusions}

1. On the basis of the conducted research, it can be concluded that the inflow of rainwater changes the values of physical and chemical indicators of water in the Biała River.

2. The duration of rain has a decisive influence on the amount of pollutants in rainwater as the pollution carried in the first 15-20 minutes of precipitation is much higher.

3. On the basis of the conducted tests, it was found that water collected from the same points, at different dates and in weather conditions, is characterized by a different degree of pollution.

The research work was carried out within the framework of the work of its own W / WBiIS / 10/2015 funded that funds for learning. 


\section{References}

1. G. Sakson, M. Zawilski, E. Badowska, A. Brzezińsk, Rainwater waste pollution as the basis for choosing how to use it, Czasopismo Inżynierii Ladowej, Srodowiska I Architektury, JCEEA, t. XXXI, z. 61 (3/I/14), lipiec-wrzesień 11,( 2014)

2. E. Eriksson, A. Baun, P.S. Mikkelsen and A. Ledin: Selection of stormwater priority pollutants, 10th International Conference on Urban Drainage, Copenhagen/Denmark, 21-26 August (2005)

3. E. Ociepa, Assessment of pollution of rain sewage to sewage systems, Inżynieria $i$ Ochrona Środowiska, t. 14, nr 4, 7, (2011)

4. J. Królikowska , Pre-treatment of rainwater sewage using a hydroseparator, Wodociagi i Kanalizacja, 4, 2. (2009)

5. S.L. Dąbkowski, K. Górska, J. Górski, B.Szeląg, Wstępne wyniki badań ścieków deszczowych w jednym z kanałów w Kielcach. Gaz, Woda i Technika Sanitarna, nr 6, 4. (2010)

6. K.L. Rule, S.D.W. Comber, D. Ross, A. Thornton, C.K. Makropoulos, R. Rautiu, Diffuse sources of heavy metals entering an urban wastewater catchment, Chemosphere, 63,8, (2006)

7. A. Wałęga, K. Chmielowski, W.z Miernik, Seminatural systems for draining and purifying rainwater from urbanized areas - legal and technical aspects, POLSKA AKADEMIA NAUK, Oddział w Krakowie, 10, Nr 6/2009,

8. G . Mangani, A . Berloni, F .Bellucci, F .Tatano, M. Maione, Water, Air and Soil Pollut, 160,15, (2005)

9. A. Wysocka - Czubaszek, W. Wojno, Seasonal variability of water chemistry in a small river in an urbanized basin, Przeglad Naukowy - Inżynieria i Ksztattowanie Środowiska $\mathrm{nr}$ 63,12, (2014)

10. S. Ballo, , M. Liu, i J. Chang,. Pollutants in stormwater runoff in Shanghai (China): Implications for management of urban runoff pollution. Progress in Natural Science, 19,7, (2009)

11. J. Królikowska, A. Królikowski, Rainwater. Discharge, development, pretreatment and use, Publisher Seidel-Przywecki, Piaseczno (2012)

12. E. Zębek, M. Szwejkowska, Evaluation of the impact of pre-treated rainwater on the number of cyanobacteria in the downtown Jeziorak lake, small at various precipitation altitudes, Ochrona środowiska, vol. 36, nr 1,(2014)

13. E. Ociepa, A. Kisiel i J. Lach, Protection of surface water against rainwater effluents from sewage systems, Proceedings of ecopole, vol. 3, no. 1, (2009)

14. M. Niemiec, B. Wiśniowska - Kielian, Contamination with heavy metals flowing down from roads taken from evaporation tanks, inżynieria ekologiczna $\mathrm{nr} 20$, (2008)

15. M. Kayhaniana, C. Suverkroppb, A. Rubyb, K. Tsayc, Characterization and prediction of highway runoff constituent event mean concentration. Journal of Environmental Management, 82, 16, (2007)

16. E. Burszta - Adamiak, J. Łomotowski, Discharge of rainwater in areas with dispersed buildings. Infrastruktura $i$ Ekologia Terenów Wiejskich, $\mathrm{nr}$ 31(1), 12, (2006)

17. A. Graham, R.L. Parker, Vertical distribution of heavy metals in Springwood Lake sediments, Richmond, Indiana. Geological Soc. of Am., 35, 6, (2003)

18. Ł. Bąk, J. Górski, K. Górska, B. Szeląg, Content of suspensions and heavy metals in selected waves of rain sewage in the urban catchment, Ochrona Środowiska, $2,3,(2012)$

19. K.L. Rule, S.D.W. Comber, D. Ross, A. Thornton, Makropoulos C.K., Rautiu R.: 
Diffuse sources of heavy metals entering an urban wastewater catchment, Chemosphere, 63, 8, (2006)

20. T. Molenda, Dynamics of changes of selected pollutants in surface runoffs of the urban catchment, Infrastructure and ecology of rural areas. $\mathrm{Nr} 4 / 3 / 2006$, POLSKA AKADEMIA NAUK, Oddział w Krakowie, 7,(2006)

21. The Act of 27 April 2001 on Environmental Protection Law (consolidated text: Journal of Laws of 2001 No. 62, item 627, as amended).

22. Act of 18 July 2001. Water law (consolidated text: Journal of Laws of 2001 No. 115 , item 1229 ,

23. Regulation of the Minister of Environment of 24 July 2006 on conditions to be met when introducing sewage into waters or into the ground, and on substances particularly harmful to the aquatic environment (Journal of Laws of 2006 No. 137, item. 984 with later changes). 